\title{
Attenuated Response to Insulin in Very Low Birthweight Infants
}

\author{
STEVEN L. GOLDMAN AND TOSHIKO HIRATA \\ Department of Pediatrics, Children's Hospital of San Francisco, San Francisco, California, USA
}

\begin{abstract}
Summary
Four hyperglycemia very low birthweight (VLBW) infants were given a constant infusion of insulin with parenteral alimentation in order to improve glucose tolerance. After an initial $45 \%$ decrease in serum glucose, intolerance recurred within hours to days despite delivery of as much as 16 units $/ \mathbf{k g} /$ hour of regular insulin. $\mathbf{R e}$ sulting serum insulin levels were as high as $\mathbf{7 2 , 0 0 0} \mu \mathrm{U} / \mathrm{ml}$. It is suggested that insulin "resistance", instead of insulin deficiency, may be responsible for glucose intolerance in some infants.
\end{abstract}

\section{Speculation}

Abnormal hepatic regulatory systems, immature enzyme systems, or abnormal insulin receptors may play a part in the glucose intolerance of the premature infant. Further studies, both in human infants and in appropriate animal models will have to be done to determine the etiology (ies) of the glucose intolerance.

Providing adequate nutrition to the VLBW infants is a significant problem because many VLBW infants do not tolerate oral feedings. While some progress has been made with the use of parenteral alimentation (9), difficulty remains with the infant who becomes hyperglycemic when given amounts of parenteral glucose thought to be necessary for growth. It is estimated that the fetus receives approximately $46 \mathrm{cal} / \mathrm{kg} /$ day as carbohydrate across the placenta by term (11). Postnatally, the caloric requirement for growth increases to $60-120 \mathrm{cal} / \mathrm{kg} /$ day $(2,3)$, most of which is supplied as carbohydrate in these tiny babies who may receive only iv nutrition for the first wk of life. Because the increase in carbohydrate is often not tolerated by the VLBW infant, the possibility of providing these infants with a constant infusion of insulin to increase their glucose utilization was investigated.

\section{MATERIALS AND METHODS}

Four preterm infants, 25-27 wk of gestation, received insulin infusions for 1-7 days. Birthweights ranged from 550-750 $\mathrm{g}$ (mean $660 \mathrm{~g}$ ) and the age of the infants at onset of study was 6-11 days (mean 9 days). Only infants with significant glucose intolerance were considered for insulin infusion. The goal of therapy was to make the infants tolerant of at least $90 \mathrm{cal} / \mathrm{kg} /$ day, usually sufficient for growth in these VLBW infants. Thus, intolerance was defined as $>2+$ glucosuria and a serum glucose $>150 \mathrm{mg} / \mathrm{dl}$ while receiving $<90 \mathrm{cal} / \mathrm{kg} /$ day as carbohydrate. Insulin was not given to infants whose hyperglycemia was secondary to sepsis, shock, or dehydration. Infants who could be given additional calories by mouth were also not given insulin. Informed consent was obtained from one or both parents and the private pediatrician.

The parenteral alimentation solutions contained 10-20\% dextose, $0.5-2.0 \mathrm{~g} / \mathrm{kg} /$ day of protein (as Freamine II), sodium, potassium, magnesium, chloride, calcium, phosphorus, and vitamins. Routine laboratory studies included serum glucose, electrolytes, calcium, phosphorus, BUN, and creatinine determinations.
The insulin was administered with a separate infusion pump "piggybacked" into the parenteral alimentation tubing as close to the vein as possible. The insulin solution consisted of $1 \%$ salt-poor albumin in $0.45 \%$ saline. The solution and tubing were changed daily. Aliquots collected at intervals over $24 \mathrm{hr}$ from the distal end of the tubing, showed no appreciable decrease in insulin concentration, eliminating the need for changing the tubing more than every $24 \mathrm{hr}(19)$.

Insulin was given at a rate of $0.1-0.2$ units $/ \mathrm{kg} / \mathrm{hr}$ and was increased as needed to maintain serum glucose between 90 and $130 \mathrm{mg} \%$ by Dextrostix. Serum insulin levels were obtained from each infant just before and at random during the insulin infusion when insulin and glucose infusion rates had been constant for at least $1 \mathrm{hr}$. Venous or capillary blood was drawn proximal to the site of insulin infusion. The serum was immediately separated and frozen at $-4^{\circ} \mathrm{C}$. The insulin values were determined in duplicate by radioimmunoassay by a modification of the assay described by Soeldner and Slone (14)).

The rates of glucose infusion were comparable before and immediately after the insulin infusion began (Fig. 1).

\section{RESULTS}

In all four babies, insulin caused an initial decrease in serum glucose of $17-68 \%$ of the preinfusion values (Fig. 1). Thus, once insulin was started, glucose infusion was increased to provide at least $90 \mathrm{cal} / \mathrm{kg} /$ day to these previously hyperglycemic infants. The glucose infusion remained constant in one infant who was hyperglycemic receiving the desired amount of glucose. The four babies became tolerant of their glucose loads, but only for a short time. Within hours to days, hyperglycemia recurred despite large increases in insulin infused which resulted in insulin levels that were over 10 times the preinfusion values (Table 1; Fig. 2).

In all four infants, hematocrit, electrolytes, calcium, and phosphorus were normal during the insulin infusion. No hypoglycemia was detected in any of the infants.

Three of the four infants survived the neonatal period: baby $\mathrm{J}$ died of pulmonary hemorrhage; baby $G$ survived, but developed chronic lung disease; babies $\mathrm{L}$ and $\mathrm{B}$ seem to be developing normally.

\section{LIMITATIONS OF METHODS}

The authors would have preferred that the group of infants were more homogeneous and that they had no clinical problems other than glucose intolerance. However, VLBW infants with a single problem are rare. Furthermore, it is usually the VLBW infant with multiple problems who has so much difficulty tolerating adequate calories.

The authors would also have liked to been able to justify a greater number of blood sugar and serum insulin determinations, thus eliminating the occasional use of Dextrostix. Unfortunately, because of the infants' small blood volumes, additional laboratory determinations, even by microtechnique, might have required additional blood transfusions. 
$J$
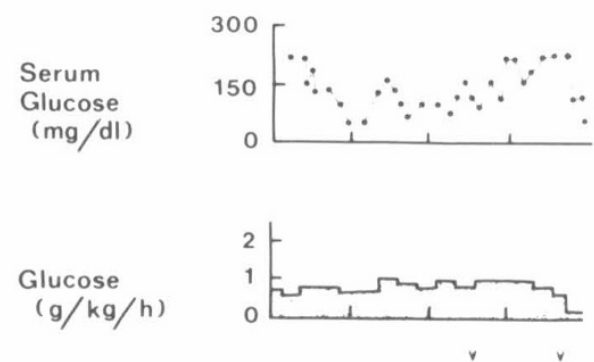

Insulin ( $\mathrm{u} / \mathrm{kg} / \mathrm{h}$ )

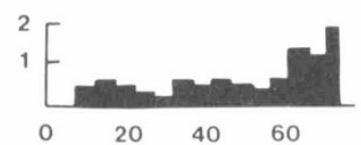

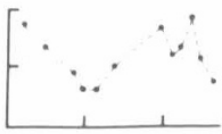

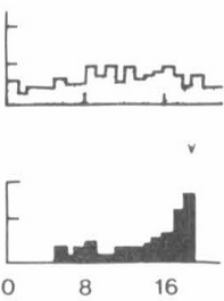

TIME (h)

B

G
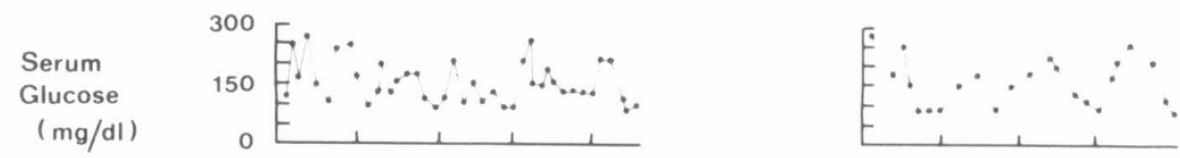

Glucose
$(\mathrm{g} / \mathrm{kg} / \mathrm{h})$
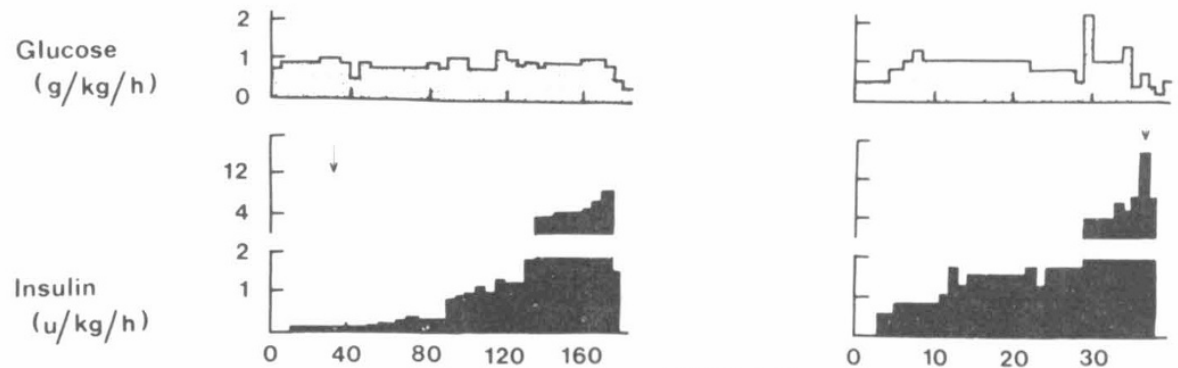

TIME (h)

Fig. 1. Serum glucose (or Dextrostix), glucose infusion, and insulin infusion are related temporally in the four infants. Arrows indicate when insulin levels were drawn. In all cases, the samples were obtained at least $1 \mathrm{hr}$ after a change in glucose or insulin infusion rate.

Table 1. Relationship between glucose intake, insulin dose, and serum glucose and insulin levels

\begin{tabular}{|c|c|c|c|c|c|c|c|c|c|}
\hline \multirow[b]{2}{*}{ Baby } & \multirow[b]{2}{*}{$\begin{array}{c}\text { Gestation } \\
\text { (wk) }\end{array}$} & \multirow[b]{2}{*}{$\begin{array}{c}\text { Birth } \\
\text { weight } \\
\text { (g) }\end{array}$} & \multicolumn{3}{|c|}{ Preinfusion } & \multicolumn{4}{|c|}{ During infusion } \\
\hline & & & $\begin{array}{c}\text { Glucose } \\
\text { intake } \\
(\mathrm{g} / \mathrm{kg} / \mathrm{hr})\end{array}$ & $\begin{array}{l}\text { Serum } \\
\text { glucose } \\
(\mathrm{mg} / \mathrm{dl})\end{array}$ & $\begin{array}{c}\text { Serum } \\
\text { insulin } \\
(\mu \mathrm{U} / \mathrm{ml})\end{array}$ & $\begin{array}{l}\text { Glucose } \\
\text { intake } \\
(\mathrm{g} / \mathrm{kg} / \mathrm{hr})\end{array}$ & $\begin{array}{l}\text { Serum } \\
\text { glucose } \\
(\mathrm{mg} / \mathrm{dl})\end{array}$ & $\begin{array}{c}\text { Insulin } \\
\text { dose } \\
(\mathrm{U} / \mathrm{kg} / \mathrm{hr})\end{array}$ & $\begin{array}{l}\text { Serum } \\
\text { insulin } \\
(\mu \mathrm{U} / \mathrm{ml})\end{array}$ \\
\hline L & 25 & 750 & 0.37 & 198 & 24.2 & 0.69 & 266 & 1.64 & 2750 \\
\hline B & 26 & 680 & 1.13 & 162 & 17.7 & 1.13 & 237 & 0.12 & 343 \\
\hline G & 26 & 660 & 0.50 & 286 & 15.8 & 0.67 & $175-250^{1}$ & 16.60 & 72000 \\
\hline \multirow[t]{2}{*}{$\mathbf{J}$} & 27 & 550 & 0.66 & 212 & 31.6 & 1.03 & $90^{1}$ & 0.58 & 600 \\
\hline & & & & & & 0.88 & $175-250^{1}$ & 3.70 & 11000 \\
\hline
\end{tabular}

\footnotetext{
${ }^{1}$ Dextrostix.
}

The authors would have preferred an experimental design in which infusion rates and alimentation solution contents were more strictly standardized. For example, modified glucose tolerance tests with and without insulin infusions would have been of interest. However, it was believed that such studies can no longer be justified in the sick VLBW infant because the potential risks are not outweighed by potential benefits.

\section{DISCUSSION}

The exact role of insulin in carbohydrate metabolism in the fetus and in the newborn is not known. Insulin can be detected in fetal pancreatic tissue as early as 11 wk of gestation (15). If insulin is important in utero, it must be provided entirely by the fetus, as maternal insulin crosses the placenta minimally (1). However, the preterm fetus, as old as 20 wk of gestation, does not respond to hyperglycemia with an increase in serum insulin (1). Even at term, an infant's insulin response to carbohydrate is sluggish (17). Thus, the premature infant's glucose intolerance has been ascribed to poor pancreatic response to hyperglycemia.

With this hypothesis, it was hoped that hyperglycemia could be avoided by providing exogenous insulin with parenteral alimentation. However, the exogenous insulin did not affect glucose tolerance as expected.

The data suggest that the small preterm infant's glucose intolerance cannot be attributed entirely to inadequate secretion of insulin. With seemingly appropriate $(10)$ preinfusion and extraordinarily high insulin levels during infusion, glucose intolerance 


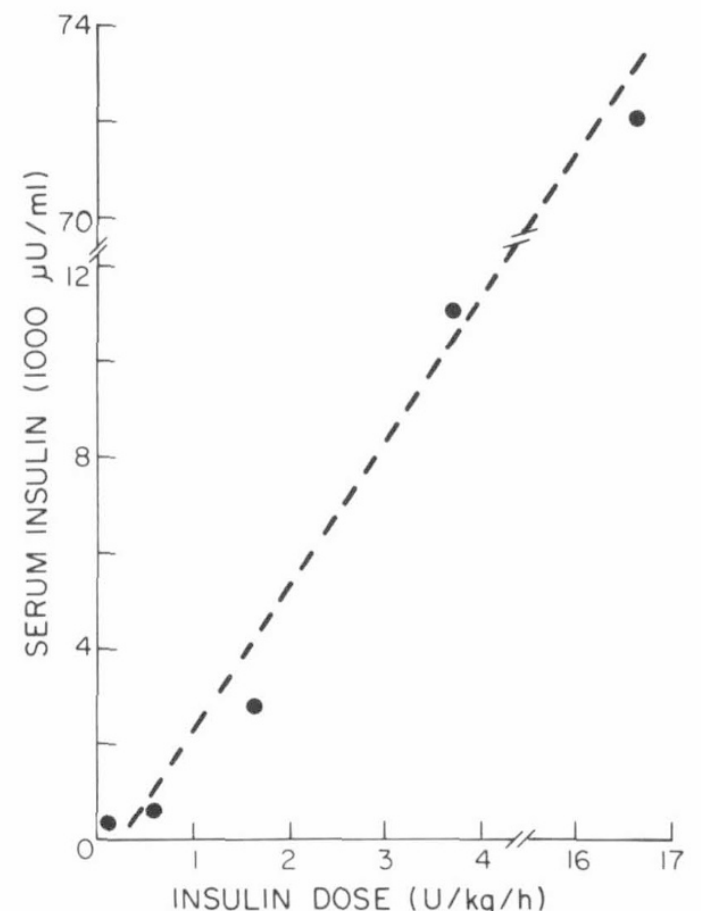

Fig. 2. There was a linear relationship between insulin dose and serum insulin levels $(r=1.0)$.

remained. Thus, insulin resistance and not insulin deficiency may be at fault.

These four infants are to be contrasted with others of similar gestational age who may only have brief periods of glucosuria or hyperglycemia. Vaucher and Walson (18) summarized their experience with four infants who developed increased glucose tolerance with low dose insulin infusion. However, the difference in the two groups may be clinically significant. The infants reported by Vaucher and Walson (18) were more mature (29vs. 26 wk of gestation), larger ( 875 vs. $660 \mathrm{~g}$ birthweight), and may have been older (3-26 vs. 6-11 days old).

Various physiologic and metabolic derangements are associated with glucose intolerance. Gram negative sepsis has been associated with hyperglycemia (7). All four infants were receiving antibiotics, but none were clinically septic or had positive bacterial cultures. Although baby B had a clinically significant patent ductus arteriosus, there was good peripheral perfusion and urine output. Three of the four infants were being ventilated with low pressures and rates, and were stable. They were not hypoxic or acidotic. The fourth infant, baby $J$, required increasing ventilatory support and died of pulmonary hemorrhage. The insulin infusion had been stopped 5 days previously.

The initial insulin response seen in all four infants may be of great importance in understanding the infant's hyperglycemia. During the infusion, there were no clinical changes noted at the time that the serum glucose began to increase. Thus, it would be difficult to attribute the hyperglycemia to changes in the infants' overall metabolic rate or to increases in circulating steroids or catecholamines. The changes in glucose clearance seen in the infants in this study must be due to changes in utilization or production. Several possibilities exist.

For example, Sherwood et al. (13) have reported that in some premature rhesus monkeys, hyperglycemia and endogenous insulin does not supress hepatic glucose output. It is unknown whether the glucose output represents gluconeogenesis or glycogenolysis. There is evidence that this phenomenon may also occur in human infants. Pollak el al. (12) demonstrated that some VLBW infants infused with glucose become hyperglycemic despite an increase in endogenous insulin secretion.

A second possibility is that VLBW infants have immature enzyme systems. Glucokinase and hexokinase are two enzymes responsible for hepatic glucose phosphorylation, an early step in glycogenesis, which decreases peripheral glucose. Hexokinase, which is not insulin dependant and which has optimum activity at low glucose concentrations is predominant in the fetal liver, with lesser amounts of glucokinase (4). The insulin stimulated synthesis of glucokinase may be minimal or easily depleted in the VLBW infant causing a short lived response to insulin. This insulin resistance may be further enhanced by insufficient activity of phosphoglucomutase, UDPG pyrophosphorylase, UDPG glucagon sysnthetase, and branching enzyme, additional enzymes necessary for the conversion of glucose to glycogen. The activity of these enzymes increase with increasing gestational age and therefore may be deficient in the VLBW infant (4).

A third possibility is that the infant's insulin receptors are abnormal in number or function. There are no reported studies of insulin receptors in the VLBW infant. However, it has been demonstrated in rats that insulin receptors increase in number as gestational age increases (5). It this is also the case in the VLBW infant, a short-lived response to insulin may be secondary to an insufficient number of functioning insulin receptors. An insufficient number of insulin receptors can also develop by "down regulation." It has been shown in tissue cultures, in adults, and in laboratory animals that there is an inverse relationship between insulin concentration and insulin receptors $(8,6,16)$. Thus, exposure to markedly elevated concentrations of exogenous insulin might similarly induce a decrease in insulin receptors in the VLBW infants in this study. Thorsson and Hintz (16) found no correlation between plasma insulin levels and insulin binding to cord blood cells in term newborns, but did find that insulin binding was significantly greater than in adults. The increase in receptor affinity and number may be related to the relatively low serum insulin in the fetus.

\section{CONCLUSION}

Insulin infusion will not be effective in reversing glucose intolerance in some infants. Therefore, insulin resistance must be considered along with insulin deficiency, as contributing to the hyperglycemia in the very immature infant.

\section{REFERENCES AND NOTES}

1. Adam, P.A. J., Teramo, K., Raiha, N., Gitlin, D., and Schwartz, R.: Human fetal insulin metabolism early in gestation. Response to acute elevation of the fetal glucose concentration and placental transfer of human insulin I-131. Diabetes, 18: 409 (1969)

2. Anderson, T. L., Nicholson, J. F., and Heird, W. C.: Controlled trial of intravenous glucose vs glucose and amino acids in premature infants. Pediatr. Res. (Abstract), 10: 351 (1976).

3. Avery, G. B., and Fletcher, A. B.: Nutrition. In: Avery, G. B.: Neonatology, p. 849 (J. B. Lippincott, Philadelphia, 1975).

4. Ballard, F. J.: Carbohydrates. In: Stave, U.: Physiology of the perinatal period. (2nd Edition) pp. 365-381 (Plenum Publishing Corporation, New York, 1978).

5. Blazquez, E., Rubalcava, B., Montesano, R., Orci, L., and Unger, R. H.: Development of insulin and glucagon binding and the adenylate cyclase response in liver membranes of the prenatal, postnatal, and adult rat: evidence of glucagon "resistance". Endocrinology, 98: 1014 (1976).

6. Bar, R. S., Gorden, P., Roth, J., Kahn, C. R., and Meyts, P. D.: Fluctuations in the affinity and concentrations of insulin receptors on circulating monocytes of obese patients: effects of starvation, refeeding, and dieting. J. Clin. Invest., 58: 1123, (1976)

7. Cryer, P. E., Herman, C. M., and Sode, J.: Carbohydrate metabolism in the baboon subjected to gram-negative ( $E$. coli) septicemia: I. Hyperglycemia with depressed insulin concentrations. Ann. Surg., 174: 91 (1971).

8. Davidson, M. B., and Kaplan, S. A.: Increased insulin binding by hepatic plasma membranes from diabetic rats. J. Clin. Invest., 59: 22 (1977).

9, Heird, W. C., and Winters, R. W.: Total parenteral nutrition. J. Pediatr., 86: 2 (1975)

10. Obershain, S. S., Adam, P. A. J., King, K. C., Teramo, K., Raivio, K. O., Raiha, N., and Schwartz, R.: Human fetal response to sustained maternal hyperglycemia. N. Engl. J. Med., 283: 566 (1970).

11. Persson, B.: Carbohydrate ad lipid metabolism in the newborn infant. Acta Anaesth. Scand. (Suppl.), 55: 50 (1974).

12. Pollak, A., Cowett, R. M., Schwartz, R., and Oh, W.: Glucose disposal in low birthweight infants during steady state hyperglycemia: Effects of exogenous insulin administration. Pediatrics, 61: 546 (1978).

13. Sherwood, W. G., Hill, D. E., and Chance, G. W.: Glucose homeostasis in preterm rhesus monkey neonates. Pediatr. Res., 11: 874 (1977).

14. Soeldner, J. S., and Slone, D.: Critical variables in the radioimmunoassay of serum insulin using the double antibody technic. Diabetes, 14: 771 (1965). 
15. Steinke, J., and Driscoll, S. G.: The extractable insulin content of pancreas from fetus and infants of diabetic and control members. Diabetes, 14: 573 (1965).

16. Thorsson, A. V., and Hintz, R. L.: Insulin receptors in the newborn. Increase in receptor affinity and number. N. Engl. J. Med., 297: 908 (1977)

17. Tobin, J. D., Roux, J. F., and Soeldner, J. S.: Human fetal insulin response after acute maternal glucose administration during labor. Pediatrics, 44: 668 (1969).

18. Vaucher, Y. E., and Walson, P. D.: Continuous insulin infusion in very low birthweight infants. Clin. Res. (Abstract) 25: 186 (1977).

19. Weisenfeld, S., Podolsky, S., Goldsmith, L., and Ziff, L.: Absorption of insulin to infusion bottles and tubing. Diabetes, 17: 766 (1968).

20. The authors thank Dr. June P. Brady and Dr. Richard L. Weinstein for helpful review of the manuscript, Ms. L. Jewel Valentine and Mrs. Carmen Acosta for

Copyright (C) 1980 International Pediatric Research Foundation, Inc. 003 1-3998/80/1401-0050\$02.00/0 preparation of the manuscript, and to the staff of the NBICU for their cooperation.

21. This study was presented, in part, at the Western Society for Pediatric Research, Carmel, California, February, 1978.

22. This research was supported by National Institutes of Health National Research Service Award HD 05390 from the National Institute of Child Health and Human Development.

23. Requests for reprints should be addressed to: Dr. Steven L. Goldman, Department of Pediatrics, University of Miami School of Medicine, P.O. Box 016960, Miami, Florida 33152, USA.

24. Received for publication April 24, 1978.

25. Accepted for publication February 12, 1979. 